DOI: https://doi.org/10.47405/mjssh.v6i11.1135

\begin{tabular}{|c|c|}
\hline 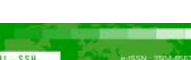 & Malaysian Journal of Social Sciences and Humanities (MJSSH) \\
\hline Malaysian Journal of & Volume 6, Issue 11, November 2021 \\
\hline (MJ-SSH) & e-ISSN : 2504-8562 \\
\hline & $\begin{array}{l}\text { Journal home page: } \\
\text { www.msocialsciences.com }\end{array}$ \\
\hline
\end{tabular}

\title{
Menerokai Faktor Kefahaman Kanak-Kanak Tadika dengan Konsep Elektrik
}

\author{
Nur Farahiyah Binti Zahar1, Lilia Binti Halim¹ \\ ${ }^{1}$ Fakulti Pendidikan, Universiti Kebangsaan Malaysia (UKM), Malaysia \\ Correspondence: Nur Farahiyah Binti Zahar (p103988@siswa.ukm.edu.my)
}

\begin{abstract}
Abstrak
Kanak-kanak tadika yang diberikan pendedahan awal dalam pembelajaran Sains dapat memberi ruang kepada mereka untuk menerokai alam sekeliling secara lebih saintifik. Malahan, pendedahan melibatkan tajuk yang abstrak seperti elektrik dapat memberi peluang kepada mereka untuk memperoleh pengetahuan yang pelbagai dalam bidang Sains. Oleh itu, kajian ini dijalankan untuk menerokai faktor-faktor yang boleh mempengaruhi kanak-kanak tadika dalam memahami tentang konsep elektrik. Reka bentuk kajian yang dilaksanakan adalah secara kajian kes dengan melibatkan kajian kualitatif. Seramai dua orang kanak-kanak berbeza jantina yang bersekolah di salah sebuah tadika swasta di Negeri Sembilan menjadi peserta dalam kajian ini. Instrumen kajian ini telah melibatkan ujian diagnostik dalam bentuk three-tier test, temu bual serta analisis dokumen dalam menerokai faktor yang mempengaruhi kefahaman kanak-kanak terhadap konsep elektrik. Hasil kajian menunjukkan bahawa miskonsepsi turut berlaku dalam kalangan kanak-kanak tadika dan terdapat pelbagai faktor yang mempengaruhi kefahaman mereka dalam memahami konsep elektrik. Antara faktor yang mempengaruhi kefahaman kanak-kanak tadika berkaitan konsep elektrik adalah faktor murid, guru, ibu bapa serta faktor luar seperti televisyen, rakan, buku dan juga internet. Menerusi faktor tersebut, didapati bahawa kanak-kanak lelaki mempunyai kefahaman yang lebih mendalam dalam konsep elektrik berbanding kanak-kanak perempuan. Tambahan itu, faktor luar yang melibatkan televisyen dilihat memberi pengaruh yang besar kepada kefahaman kanak-kanak tadika dalam memahami konsep elektrik. Justeru, faktor yang terlibat boleh membantu guru dalam mencari jalan penyelesaian untuk mengelakkan berlakunya miskonsepsi dalam kalangan kanak-kanak dan memberi penjelasan secara saintifik kepada mereka. Hal ini supaya kanak-kanak tidak membawa miskonsepsi ke peringkat yang seterusnya.
\end{abstract}

Kata kunci: miskonsepsi, kanak-kanak, elektrik, Sains, faktor

\section{Exploring the Understanding Factors of Kindergarten Children with the Concept of Electricity}

\begin{abstract}
Kindergarten children who are given early exposure for learning Science, can give them space to explore the environment scientifically. In fact, exposure involving abstract topics such as electricity can give them the opportunity to acquire diverse knowledge in Science. Thus, this study was conducted to explore the factors that can influence kindergarten children in understanding the concept of electricity. The design of the study is a case study involving qualitative research. The participants of this study are two kindergarten children with different gender from one of private kindergartens in
\end{abstract}


Negeri Sembilan. The instruments involved in this study are diagnostic tests in the form of three-tier tests, interviews and document analysis in exploring factors that affect children's understanding of the concept of electricity. The results showed that misconceptions also occurred among the kindergarten children and there were various factors that influenced them to understand the concept of electricity. Factors that influence the understanding of kindergarten children in electricity are the factors of students, teachers, parents, and external factors such as television, friends, books, and the Internet. Through these factors, it was found that the boy has a deeper understanding of the concept than the girl. In addition, external factors involving television are seen to have a significant influence on the understanding of kindergarten children. Therefore, the factors involved can help teachers in finding solutions to prevent misconceptions among children and give them scientific explanations. Thus, the children will not bring misconceptions to the next level.

Keywords: misconception, children, electric, Science, factor

\section{Pengenalan}

Kanak-kanak terkenal dengan sikap suka menerokai dunia di sekeliling mereka untuk memahami sesuatu perkara. Pembelajaran Sains yang diterapkan bagi kanak-kanak tadika dapat memberi peluang mereka menerokai dan mengkaji sesuatu pengetahuan dengan lebih saintifik. Berdasarkan Mazlini et al. (2017), pendedahan Sains yang diberikan pada peringkat awal seperti di prasekolah dan tadika dapat mengasah bakat yang ada dalam diri kanak-kanak. Pendedahan Sains di peringkat tadika dapat membantu kanak-kanak memahami tentang Sains dengan lebih baik kerana terdapat kesinambungan pembelajaran yang akan dipelajari di peringkat yang seterusnya (McClure et al., 2017) seperti peringkat sekolah rendah. Aktiviti yang dijalankan semasa proses pembelajaran Sains juga dapat membina sifat yang positif dalam diri serta melengkapkan mereka pelbagai kemahiran yang ada (Alveirinho et al., 2017; Can et al., 2017). Pembelajaran kanak-kanak akan lebih bermakna serta menarik semasa mempelajari tentang Sains apabila menggunakan variasi pembelajaran kepada mereka (Bustamante et al., 2018). Sebagai contoh, aktiviti yang melibatkan kemahiran proses Sains yang ada seperti pemerhatian, mengelas, membuat inferens, meramal, mengukur, berkomunikasi, membuat hipotesis dan melaksanakan eksperimen (Norazizah et al., 2019).

Berdasarkan teori Piaget, perkembangan kognitif kanak-kanak terbahagi kepada empat peringkat iaitu sensori motor, praoperasi, operasi konkrit dan juga operasi formal (Ojose, 2008). Kanak-kanak tadika berada pada peringkat praoperasi yang mana berada dalam kategori umur dua hingga tujuh tahun. Pada peringkat ini, perkembangan bahasa mula berlaku (Piaget, 1952). Orang yang berada di sekeliling kanak-kanak dapat membantu perkembangan bahasa mereka menerusi komunikasi antara dua hala untuk meningkatkan kosa kata mereka. Tambahan itu, berdasarkan teori konstruktivisme, individu tidak boleh memahami sesuatu maklumat tersebut secara automatik tetapi boleh membentuk pengetahuan sedia ada berdasarkan pengalaman. Mereka akan membuat gambaran baru di minda menerusi pembelajaran yang aktif. Perkara yang dilalui oleh kanak-kanak menjadikan mereka membentuk sesuatu pengetahuan baru. Tanpa bimbingan yang betul, miskonsepsi boleh berlaku dalam kalangan kanak-kanak. Berdasarkan Suliyanah et al. (2018), salah satu halangan bagi murid dalam mempelajari tentang Sains adalah miskonsepsi. Malahan, kajian yang dijalankan oleh Brooks \& Gelman (1998) menunjukkan bahawa kanak-kanak pada peringkat praoperasi sudah mula bertanyakan tentang topik yang abstrak. Hal ini menunjukkan bahawa kanak-kanak sudah mula menerokai dunia sekeliling dengan lebih mendalam.

Konsep elektrik merupakan salah satu konsep yang terdapat dalam pembelajaran Sains. Terdapat kajian yang menyatakan bahawa konsep ini merupakan antara konsep yang menjadi kesukaran bagi murid untuk mempelajarinya. Hal ini terjadi disebabkan terdapat murid yang menyatakan bahawa tajuk ini merupakan antara tajuk yang abstrak untuk dipelajari (Kollöffel \& De Jong, 2013) terutama bagi murid sekolah menengah yang mempelajari konsep ini dalam subjek Fizik (Halim et al., 2019). Di samping itu, terdapat juga salah faham atau miskonsepsi yang berlaku dalam kalangan murid dalam mempelajari tentang konsep elektrik (Halim et al., 2019; Kurniawan \& Maryanti, 2018; Marhadi et al., 2019; Suma 
et al., 2019). Miskonsepi adalah perkara yang melibatkan salah faham tentang sesuatu konsep dan kepercayaan yang tidak saintifik dan tanggapan yang tidak difahami (Moddley dan Gaigher, 2017). Miskonsepsi yang berlaku disebabkan konsep elektrik boleh menjadi penghalang kepada murid untuk memahami konsep Sains dengan betul.

Miskonsepsi boleh berlaku dalam kalangan kanak-kanak tadika apabila mereka memahami sesuatu konsep secara tidak tepat atau saintifik (Mareshal, 2016). Berdasarkan teori Piaget, skema pengetahuan boleh terbentuk dalam fikiran mereka. Proses asimilasi berlaku apabila jika input pengetahuan yang diperoleh selari dengan pengetahuan sedia ada dalam diri mereka. Namun begitu, proses akomodasi pula sebaliknya boleh berlaku sebaliknya. Proses akomodasi berlaku jika skema pengetahuan yang diperoleh tidak selari dengan pengetahuan sedia ada mereka. Kesukaran kanak-kanak dalam melaksanakan proses akomodasi boleh menyebabkan berlakunya miskonsepsi. Permasalahan yang melibatkan miskonsepsi perlu diatasi untuk mengelakkan berlakunya permasalahan yang akan datang dalam sesuatu pembelajaran (Ameyaw \& Sarpong, 2011; Gürefe et al., 2014) Oleh itu, miskonsepsi perlu diatasi sejak awal lagi supaya murid boleh memahami konsep Sains dengan baik dan secara saintifik.

Faktor yang menjadi penyumbang kepada kefahaman seseorang murid terhadap konsep perlu diketahui supaya miskonsepsi yang terjadi kepada mereka dapat diatasi. Berdasarkan kajian lepas, terdapat pelbagai faktor yang menyebabkan berlakunya miskonsepsi disebabkan oleh konsep elektrik. Antara faktor yang menjadi penyebab berlakunya miskonsepsi adalah disebabkan oleh faktor murid Bestiantono et al., 2018; Sholihat et al., 2017; Suma et al., 2019), faktor guru (Bayuni et al., 2018; Halim et al., 2019) dan pelbagai lagi. Justeru, kajian ini dilaksanakan untuk meneroka faktor yang boleh mempengaruhi kefahaman kanak-kanak tadika dalam konsep elektrik berdasarkan jantina yang berbeza. Ujian diagnostik turut dijalankan untuk meneroka kefahaman yang diperoleh oleh kanakkanak tadika tersebut dan temu bual dijalankan dapat memperoleh secara lebih mendalam faktor yang mempengaruhi kefahaman mereka.

\section{Sorotan Literatur}

\section{Pendidikan Sains di Tadika}

Pendidikan di Malaysia yang wujud memberi peluang pelbagai peringkat umur untuk mendapatkan pengetahuan. Bermula daripada peringkat tadika lagi, pendidikan secara khusus telah disediakan untuk murid memperoleh pengetahuan dan pengalaman. Pendidikan perlu dititik beratkan sejak awal lagi seperti pembelajaran yang telah disediakan pada peringkat tadika atau prasekolah. Tambahan, penekanan Pendidikan Sains pada peringkat awal seperti di tadika dapat mengalakkan pendedahan awal kepada kanak-kanak memperoleh pengetahuan dalam menerokai alam sekeliling mereka (Ravanis, 2017). Hal ini kerana pendedahan melibatkan Pendidikan Sains dapat mengasah kemahiran dan bakat yang ada dalam diri kanak-kanak di tadika (Can et al., 2017). Malahan, Ravanis (2017) berpendapat bahawa pendedahan Sains pada peringkat tadika juga mampu mengalakkan kanak-kanak teruja untuk menerokai dan memerhatikan dunia sekeliling mereka secara saintifik.

Pendidikan Sains perlu diterapkan sejak awal lagi terutama pada peringkat tadika kerana mampu mewujudkan insan yang dapat berdaya saing secara sihat serta menggunakan teknologi secara baik seiring dengan Falsafah dalam Pendidikan Sains. Menerusi Pendidikan Sains, sikap saintifik dapat dibina dalam diri murid seperti menjadi insan yang lebih teliti dan tersusun (Mazlini et al. 2016; Suppiah et al., 2016; Trundle \& Sucker, 2015) serta dapat meningkatkan kemahiran interaksi dua hala Bustamante et al., 2017; Bustamante et al., 2018; Mazlini et al., 2016). Di samping itu, kajian yang dilaksanakan oleh Trundle \& Smith (2017) menunjukkan bahawa pendedahan konsep Sains pada peringkat awal dapat meningkatkan perkembangan kognitif, emosi (Bustamante et al., 2018) dan sosial kanak-kanak. 


\section{Miskonsepsi Berkaitan Elektrik}

Pemahaman yang tidak tepat berkaitan dengan konsep saintifik juga boleh dimaksudkan sebagai miskonsepsi (Berg, 1991; Clement, 1993; Galvin \& Simmie, 2015; Sanger \& Greenbowe, 1997). Malahan, miskonsepsi juga boleh dikaitkan dengan defenisi seperti salah faham, kekeliruan serta pemikiran yang tidak menepati konsep sebenar (Hisyamuddin \& Amir Hamzah, 2012). Elektrik merupakan salah satu subjek Sains yang mudah terdedah kepada berlakunya miskonsepsi. Kesalahfahaman terhadap elektrik ini telah banyak diakui dan terdapat pelbagai kajian yang dilaksanakan sejak 1970-an lagi dengan melibatkan pelbagai kes yang berlaku. Antara sebab berlakunya perkara ini adalah kerana anggapan murid bahawa konsep elektrik merupakan pembelajaran yang abstrak sehingga menyebabkan mereka kurang berminat untuk mempelajari konsep ini secara saintifik. Miskonsepsi boleh terjadi tanpa peringkat umur terutama dalam melibatkan konsep elektrik (Kumandas, 2015).

Terdapat pelbagai kajian lepas yang telah melaksanakan penyelidikan berkaitan miskonsepsi elektrik sama ada murid di sekolah, pelajar universiti dan juga melibatkan guru. Pelbagai kaedah yang dijalankan dalam mengenal pasti miskonsepsi yang berlaku. Sebagai contoh, ujian diagnostik yang melibatkan pelbagai peringkat seperti two-tier test, three-tier test dan juga four-tier test. Ujian diagnostik yang digunakan oleh penyelidik dalam menentukan sama ada berlakunya miskonsepsi mempunyai kekuatan dan kelemahan masing-masing (Gurel, Ervilmaz \& McDemot, 2015; Soehatro, 2019. Kelebihan penggunaan three-tier test adalah terdapat ruang untuk murid memilih sama ada yakin atau sebaliknya terhadap jawapan yang diberikan (Aydeniz et al., 2017; Taslidere 2016; Soerharto et al. 2019). Miskonsepsi dapat dikenal pasti menerusi ujian diagnostik berbentuk three-tier test yang digunakan. Namun begitu, kelemahan yang melibatkan three-tier test adalah boleh berlakunya kesilapan dalam menentukan sama ada keyakinan jawapan yang diberikan adalah penyebab kepada miskonsepsi atau kurang pengetahuan terhadap jawapan yang telah diberikan oleh peserta kajian (Gurel et al., 2015; Soehatro 2019).

\section{Faktor yang mempengaruhi miskonsepsi}

Pelbagai faktor yang boleh menjadi penyebab berlakunya miskonsepsi sesuatu topik terutamanya dalam pembelajaran Sains. Antara salah satu faktor yang terlibat disebabkan murid itu sendiri. Murid sendiri kurang berminat untuk mempelajari subjek elektrik (Halim et al., 2019; Leong, 2012). Perkara ini terjadi kerana mereka merasakan bahawa tajuk ini berbentuk abstrak. Di samping itu, murid mengalami konflik kognitif berkaitan tajuk ini yang memberi kesan kepada prestasi pembelajaran murid (Bucat, 2015; Kang et al., 2010; Nixon et al., 2016; Sadler et al., 2013). Konflik kognitif berlaku adalah disebabkan oleh perbezaan pengetahuan sedia ada dalam diri murid dalam menghubungkan maklumat yang baru. Apabila perkara ini berlaku, murid mudah terdedah kepada miskonsepsi terhadap sesuatu pembelajaran yang dipelajari. Hal ini disebabkan terdapat percanggahan maklumat yang tepat tentang sesuatu konsep yang dipelajari (Bestiantono et al., 2019).

Malahan, jawapan yang diberikan oleh murid semasa menjawab soalan juga menjadi faktor miskonsepsi terjadi dalam kalangan murid (Halim et al., 2018; Sholihat et al., 2017). Cara pemberian jawapan yang tidak bertepatan dengan konsep saintifik dapat menunjukkan miskonsepsi berlaku dalam diri murid. Terdapat murid yang hanya meneka sahaja jawapan yang diberikan tanpa melibatkan fakta yang betul (Diani et al., 2018). Hal ini menunjukkan bahawa mereka tidak memahami sesuatu konsep yang dipelajari dengan betul dan tepat (Sholihat et al., 2017). Justeru, perkara sedemikian telah banyak mempengaruhi kefahaman mereka terhadap sesuatu tajuk yang dipelajari dan boleh menyebabkan miskonsepsi terjadi.

Selain itu, faktor lain yang boleh menjadi penyebab berlakunya miskonsepsi adalah disebabkan oleh guru (Bayuni et al., 2018; Desstya et al., 2019; Halim et al., 2019; Kiray et al., 2015). Guru memainkan peranan yang penting dalam menyampaikan maklumat atau ilmu tentang konsep saintifik. Mereka perlu menyampaikan maklumat secara tepat kerana penerangan yang kurang jelas boleh menyebabkan berlakunya miskonsepsi (Azaman et al., 2009; Halim et al., 2019). Malahan, terdapat guru yang tidak memahami sesuatu konsep secara mendalam (Arslan et al., 2012; Halim, et al., 2019; Kiray et al., 
2015). Hal ini menjadi lebih parah apabila mereka tidak tahu cara yang betul dalam mengendalikan masalah ini (Chen et al., 2020; Sadler, 2013). Perkara tersebut sedikit sebanyak akan menjejaskan kefahaman murid dalam memahami sesutu konsep yang saintifik.

Di samping itu, cara pengajaran guru yang menggunakan keadah lama turut menjadi penyumbang berlakunya miskonsepsi ini (Taufik, 2012). Terdapat guru yang masih menggunakan kaedah lama seperti berpusatkan guru dalam menyampaikan konsep tertentu (Kurniawan \& Arief, 2015). Hal ini menyebabkan murid terdedah kepada miskonsepsi menerusi proses pengajaran guru menggunakan kaedah yang lama. Malahan, penggunaan bahan pengajaran yang tidak bersesuaian oleh guru turut menjadi faktor berlakunya miskonsepsi (Taber, 2014). Perkara ini perlu diatasi oleh guru dalam menjelaskan sesuatu konsep saintifik yang tepat. Tambahan, komunikasi dua hala yang kurang efektif juga dapat menjejaskan proses pembelajaran. Murid sukar bertanya soalan kepada guru yang mengajar kerana berasa takut untuk melakukan kesilapan (Halim et al., 2018; Halim et al., 2019). Maka, miskonsepsi boleh berlaku apabila murid tidak jelas dengan konsep yang telah dipelajari berdasarkan pengajaran guru.

Tambahan itu, faktor luar turut memainkan peranan mempengaruhi miskonsepsi yang berlaku. Faktor luar yang boleh menyebabkan berlakunya miskonsepsi adalah buku teks atau buku rujukan yang ada (Kurniawan \& Maryanti, 2018; Sanders \& Makotsa, 2016; Yagbasan \& Gulcicek, 2003). Penggunaan istilah yang kurang tepat atau tidak sesuai dapat menjejaskan kefahaman murid terhadap sesuatu konsep. Kekeliruan dalam diri murid dengan penggunaan perkataan yang tidak bersesuaian oleh penulis sedikit sebanyak menyebabkan miskonsepsi berlaku. Hal ini kerana buku teks dan buku rujukan merupakan salah satu rujukan yang penting bagi guru dan murid dalam memahami sesuatu topik (Sanders \& Makotsa, 2016). Berdasarkan pernyataan di atas, terdapat pelbagai faktor yang menyebabkan berlakunya miskonsepsi seperti murid, guru dan faktor luar.

\section{Metod Kajian}

Kajian yang dijalankan adalah kajian kes yang melibatkan kes tunggal. Kajian kes ini melibatkan faktor yang mempengaruhi kanak-kanak memahami pembelajaran Sains yang melibatkan konsep elektrik. Reka bentuk kajian adalah berbentuk kualitatif dengan melibatkan sampel bertujuan. Penggunaan sampel bertujuan dipilih kerana dalam mendapatkan maklumat tertentu, hanya individu tertentu dipilih (Merriam, 2009). Seramai dua orang kanak-kanak tadika berumur enam tahun yang mempunyai jantina yang berbeza menjadi peserta dalam kajian ini. Berdasarkan Patton (2002), pemilihan sampel dalam kajian kualitatif tidak melibatkan bilangan yang ramai tetapi lebih bertumpu kepada tujuan sesuatu kajian dilakukan. Kajian juga dijalankan di salah sebuah tadika swasta di Negeri Sembilan.

\section{Instrumen kajian}

Instrumen yang dijalankan dalam kajian ini adalah ujian diagnostik, temu bual serta analisis dokumen dengan melibatkan dokumen rasmi. Ujian diagnostik yang digunakan dalam kajian ini ini adalah menggunakan three-tier test. Three-tier test adalah ujian diagnostik yang digunakan dalam menentukan jika terdapat miskonsepsi yang berlaku terhadap sesuatu konsep yang digunakan. Terdapat tiga peringkat soalan dalam ujian diagnostik tersebut untuk dijawab. Kesahan pakar diperoleh sebelum ujian diagnotik ini dijalankan kepada kanak-kanak tadika.

Selain itu, pengukuran kajian ini melibatkan temu bual secara separa berstruktur. Temu bual dijalankan kepada dua orang kanak-kanak tadika yang terdiri daripada lelaki dan perempuan untuk meneroka faktor yang mempengaruhi kefahaman mereka terhadap pembelajaran Sains melibatkan elektrik. Di samping itu, analisis dokumen rasmi turut dijalankan. Hal ini kerana maklumat yang lebih terperinci dapat diperoleh menerusi mesej tertentu dalam bentuk bahan bercetak, bergambar atau yang disiarkan berdasarkan analisis dokumen. 


\section{Pengumpulan data}

Data dalam kajian ini dikumpul menerusi tiga keadaan iaitu ujian diagnostik miskonsepsi elektrik, temu bual ke atas peserta dan analisis dokumen.

Ujian ini dilaksanakan secara three-tier test dalam menentukan sama ada berlakunya miskonsepsi atau tidak dalam kalangan kanak-kanak tadika tersebut. Kajian ini menggunakan three-tier test kerana ujian diagnostik ini sering diguna pakai oleh para pengkaji dalam menentukan sama ada berlaku miskonsepsi dalam kalangan murid di peringkat sekolah (Aydeniz et al., 2017; Sen \& Yilmaz 2017; Taslidere 2016). Kajian ini telah memberikan ujian diagnostik miskonsepsi secara three-tier test kepada kanakkanak tadika tersebut. Kanak-kanak perlu menjawab sebanyak tiga soalan utama dalam ujian yang dikemukakan oleh pengkaji secara bersemuka untuk mendapatkan maklumat kefahaman mereka terhadap elektrik. Jawapan yang diberikan oleh kanak-kanak tersebut dapat menentukan sama ada berlakunya miskonsepsi atau tidak. Analisis terhadap jawapan yang diberikan dapat memberi gambaran terhadap kefahaman mereka terhadap konsep elektrik.

Temu bual yang dijalankan dalam kajian ini adalah melibatkan temu bual secara separa berstruktur. Menurut Schensul et al. (1999), temu bual separa berstruktur merupakan salah satu kaedah yang terbaik dalam menentukan faktor yang dijalankan secara mendalam. Dalam kajian ini, dua orang kanak-kanak tadika ditemu bual dalam mendapatkan secara lebih terperinci berkenaan faktor-faktor yang boleh mempengaruhi kefahaman mereka terhadap elektrik. Kebenaran daripada pihak pengetua sekolah diperoleh sebelum temu bual dijalankan. Kanak-kanak akan diberikan soalan ujian diagnostik miskonsepsi secara temu bual pada permulaan dan kemudian mereka ditemu bual dengan soalan yang menjurus kepada faktor yang boleh menyebabkan miskonsepsi berlaku.

Soalan temu bual yang dijalankan telah dibentuk terlebih dahulu bagi mendapatkan maklumat yang mendalam terhadap jawapan yang diberikan oleh kanak-kanak tersebut. Tambahan, soalan tambahan turut disoal semasa kajian dijalankan untuk melihat sejauh mana kefahaman mereka terhadap elektrik berdasarkan jawapan yang telah diberikan sebelum itu. Malahan, rakaman secara audio turut dijalankan semasa temu bual dilaksanakan serta catatan melibatkan bukan lisan turut dicatatkan. Soalan tambahan dilaksanakan berdasarkan keperluan kepada jawapan yang diberikan oleh kanak-kanak berkenaan. Temu bual yang dijalankan melibatkan temu bual perseorangan supaya jawapan yang diberikan merupakan hasil kefahaman mereka sendiri.

Selain daripada ujian diagnostik miskonsepsi serta temu bual, analisis dokumen turut dijalankan dalam kajian ini. Analisis dokumen yang dijalankan dalam kajian ini melibatkan dokumen rasmi. Dokumen merupakan sumber data ketiga terpenting dalam kajian kualitatif dalam menyokong data yang terdapat pada kaedah temu bual dan pemerhatian serta bukti tambahan dalam mengumpul data (Merriam 2009). Dokumen rasmi yang digunakan dalam kajian ini adalah buku teks serta buku latihan Sains kanakkanak tadika berumur enam tahun. Maklumat yang melibatkan kandungan teks, gambar atau simbol dianalisis untuk menentukan sama ada terdapat faktor boleh berlakunya miskonsepsi menerusi dokumen rasmi ini.

\section{Analisis data}

Analisis data dalam kajian ini dilaksanakan berdasarkan model Interaktif yang dikemukakan oleh Miles \& Huberman (1994). Tiga komponen utama yang terlibat adalah penyaringan data, pemaparan data dan juga melakukan kesimpulan daripada hasil kajian yang dilaksanakan. Data yang diperoleh menerusi instrumen yang digunakan dianalisis secara naratif dan dapatan temu bual dikategorikan mengikut tema yang tertentu.

\section{Hasil Kajian}

Pengkaji telah menggunakan ujian diagnostik three-tier test untuk meneroka kefahaman yang diperoleh oleh kanak-kanak melibatkan konsep elektrik. Ujian ini dilaksanakan ke atas dua orang kanak- kanak 
tadika secara bersemuka dan jawapan yang diberikan telah direkodkan. Kemudian, pengkaji membuat analisis terhadap jawapan yang diberikan dengan menggunakan kajian yang telah dilaksanakan oleh Suma et al. (2019) berdasarkan Jadual 1.

Jadual 1: Kategori kefahaman kanak-kanak

\begin{tabular}{cccc}
\hline \multicolumn{2}{c}{ Jawapan kanak-kanak pada setiap peringkat } & \multirow{2}{*}{ Kategori kefahaman } \\
\cline { 1 - 3 } Peringkat 1 (Tier 1) & Peringkat 2 (Tier 2) & Peringkat 3 (Tier 3) & \\
\cline { 1 - 3 } Betul & Betul & Yakin & Pengetahuan saintifik \\
Betul & Betul & Tidak yakin & Kurang pengetahuan \\
Betul & Salah & Tidak yakin & Kurang pengetahuan \\
Salah & Betul & Tidak yakin & Kurang pengetahuan \\
Salah & Salah & Tidak yakin & Kurang pengetahuan \\
Betul & Salah & Yakin & Miskonsepsi \\
Salah & Salah & Yakin & Miskonsepsi \\
\hline
\end{tabular}

Sumber: Suma et al. (2019)

Rajah 1 menunjukkan salah satu contoh soalan ujian diagnostik yang digunakan ke atas kanak-kanak tadika dengan menggunakan three-tier test. Ujian diagnostik ini terdiri daripada tiga peringkat soalan dan setiap peringkat mempunyai beberapa pilihan jawapan. Pada peringkat pertama, kanak-kanak perlu memilih jawapan yang tepat kepada soalan yang diberikan manakala soalan kedua pula merupakan sebab pemilihan jawapan kepada peringkat pertama. Peringkat ketiga pula melibatkan kepada keyakinan kanak-kanak tersebut terhadap jawapan yang telah diberikan pada peringkat sebelum itu, Sebanyak tiga soalan utama diberikan kepada kanak-kanak tersebut untuk menentukan kategori kefahaman mereka. Menerusi jawapan yang diberikan juga, miskonsepsi berkaitan elektrik dapat dikenal pasti menerusi kanak-kanak.

Rajah 1: Soalan ujian diagnostik menggunakan three-tier test

\section{Soalan pertama}

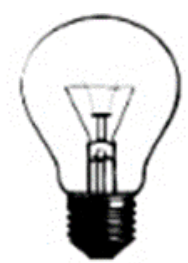

Apakah nama objek di atas?

\section{A) Jawapan}

Sila pilih salah satu jawapan berikut:
A. Lampu suluh
B. Mentol
C. Suis
D. Sel kering 


\section{B) Ulasan kepada jawapan yang diberikan}

Sila nyatakan sebab pemilihan jawapan yang telah diberikan di bahagian 1A:

A. Mengeluarkan cahaya apabila dipasang

B. Membekalkan tenaga elektrik

C. Membenarkan arus elektrik mengalir

D. Menyambung komponen elektrik

\section{C) Tahap keyakinan}

Tandakan $(\sqrt{ })$ pada tahap keyakinan jawapan yang telah diberikan di bahagian 1B.

Yakin ( )

Tidak yakin ( )

Jadual 2 merupakan kategori kefahaman kanak-kanak tadika yang diperoleh oleh kanak-kanak lelaki dan kanak-kanak perempuan berdasarkan soalan ujian diagnostik. Jika dilihat kepada soalan pertama, kanak-kanak perempuan menguasai konsep tersebut manakala kanak-kanak lelaki mengalami miskonsepsi apabila menyatakan bahawa mentol sebagai lampu suluh. Di samping itu, kanak-kanak lelaki teresebut juga telah tersalah konsep tentang fungsi mentol. Dia telah memberi jawapan yang fungsi mentol sebagai penyambung kepada komponen elektrik berbanding konsep sebenar adalah mengeluarkan cahaya apabila dipasang. Justeru, kanak-kanak lelaki berkenaan berada pada kategori miskonsepsi kerana yakin terhadap jawapan yang telah diberikan melibatkan fungsi mentol.

Jadual 2: Kefahaman kanak-kanak menerusi ujian diagnostik miskonsepsi

\begin{tabular}{llll}
\hline Soalan & Konsep Sains & Kanak-kanak lelaki & Kanak-kanak perempuan \\
\hline Soalan 1 & Fungsi mentol & Miskonsepsi & Pengetahuan saintifik \\
Soalan 2 & Konduktor penebat & Kurang pengetahuan & Miskonsepsi \\
Soalan 3 & Litar elektrik & Miskonsepsi & Miskonsepsi \\
\hline
\end{tabular}

Soalan kedua pula melibatkan konsep konduktor dan penebat. Kanak-kanak perempuan telah menganggap bahawa pemadam merupakan bahan konduktor yang dapat mengalirkan elektrik. Konsep yang sebenar adalah klip kertas besi merupakan bahan konduktor yang boleh mengalirkan elektrik berbanding pemadam yang merupakan bahan penebat. Hal ini menunjukkan kanak-kanak perempuan berada pada peringkat miskonsepsi berkaitan konsep penebat dan konduktor. Namun begitu, kanakkanak lelaki pula berada pada peringkat kurang pengetahuan kerana tidak yakin dengan jawapan yang diberikan apabila memberikan jawapan yang salah bahawa sudu plastik merupakan bahan konduktor.

Soalan ketiga pula berkaitan tentang faktor yang menyebabkan litar tidak menyala. Kedua-dua kanakkanak tersebut telah memberikan jawapan yang tidak tepat. Kanak-kanak lelaki berkenaan memberikan jawapan yang tidak tepat pada peringkat B. Dia telah beranggapan penggunaan sel kering yang baru menyebabkan mentol tidak menyala. Kanak-kanak perempuan pula telah mengalami miskonsepsi pada soalan ini kerana merasakan mentol tidak menyala kerana suis tertutup. Kedua-dua mereka mengalami miskonsepsi pada soalan ini dengan memberikan jawapan yang berbeza. Hal ini menunjukkan kanakkanak tadika tidak terlepas daripada berlaku miskonsepsi berkaitan elektrik.

\section{Temu bual}

Hasil temu bual yang dijalankan ke atas dua orang kanak-kanak tadika berkenaan, terdapat beberapa tema yang dikenal pasti. Tema tersebut dikategorikan sebagai faktor yang mempengaruhi kefahaman 
mereka terhadap konsep elektrik. Antara faktor-faktor yang terlibat adalah faktor murid, faktor ibu bapa, faktor guru dan juga faktor luar seperti buku, televisyen, rakan dan juga internet.

\section{Faktor murid}

Antara salah satu faktor yang boleh mempengaruhi kefahaman kanak-kanak dalam memahami konsep elektrik ini adalah murid itu sendiri. Minat dalam mempelajari konsep elektrik itu sendiri dapat membantu mereka memahami konsep Sains ini dengan lebih baik. Hal ini boleh dilihat apabila kanakkanak lelaki itu mengatakan minatnya dalam mempelajari elektrik:

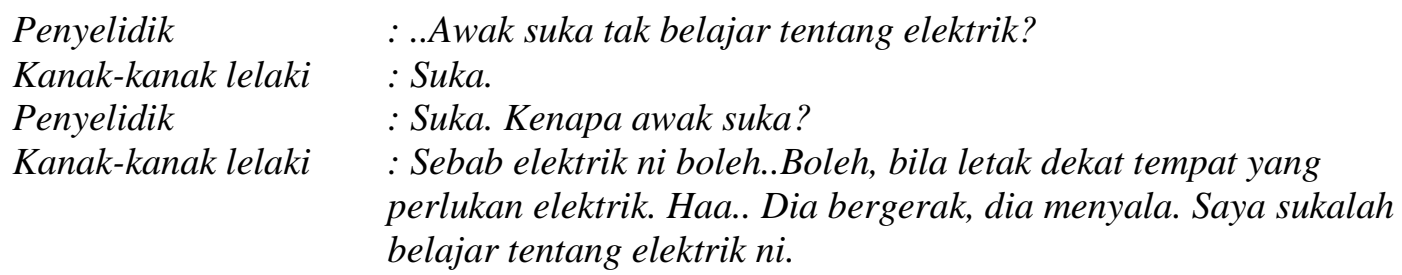

Namun begitu, berbeza pula dengan kanak-kanak perempuan apabila ditanya minat mereka terhadap konsep elektrik. Mereka kurang berminat dalam mempelajari tentang elektrik. Kanak-kanak berkenaan menyatakan bahawa tidak biasa dengan istilah berkaitan elektrik:

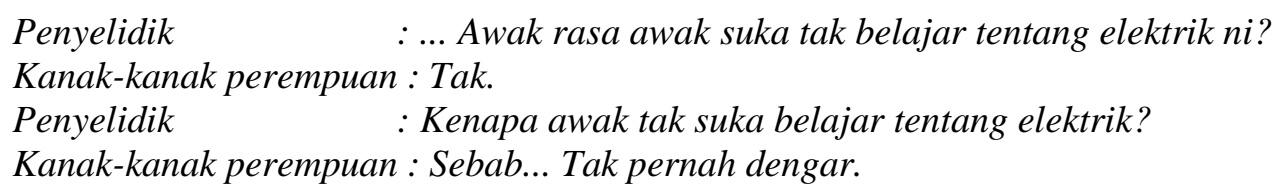

Kurang pendedahan terhadap konsep ini menyebabkan mereka tidak berminat untuk memahami konsep elektrik. Kajian yang dijalankan oleh Halim et al. (2019), menyatakan bahawa murid tidak berminat dalam mempelajari konsep elektrik dan hal ini boleh menyebabkan berlakunya miskonsepsi. Walaupun minat memainkan peranan yang penting dalam memahami konsep elektrik, kefahaman sedia ada dalam diri mereka juga boleh menyebabkan miskonsepsi berlaku. Hal ini boleh dilihat apabila kanak-kanak perempuan dalam kajian ini memberikan jawapan yang kurang tepat dalam temu bual yang dijalankan terhadap konsep elektrik:
Penyelidik
.... Fikir pasal bateri? Pernah terfikir?
Kanak-kanak perempuan : Pernah sikit-sikit.
Penyelidik : Pernah sikit-sikit. Macam mana awak terfikir?
Kanak-kanak perempuan : Sebab waktu tu saya cakap sendiri.
Penyelidik : Cakap sendiri. Macam mana awak cakap sendiri tu?
Kanak-kanak perempuan : Saya cakap kawan saya.
Penyelidik : Cakap macam mana? Macam mana awak cakap?
Kanak-kanak perempuan : Cakap macam... Yang elektrik tu masuk dekat handphone.

\section{Faktor guru}

Selain daripada murid, faktor guru juga mempengaruhi kefahaman murid terhadap konsep elektrik ini. Cara pengajaran yang ditunjukkan oleh guru memainkan peranan yang penting dalam memberi kefahaman kepada murid. Penyampaian guru yang menarik akan mempengaruhi kefahaman mereka terhadap konsep elektrik. Hal ini boleh dilihat apabila kanak-kanak lelaki yang menyatakan bahawa dia lebih mudah faham tentang konsep elektrik apabila belajar secara bersendirian atau bersama rakan berbanding guru:

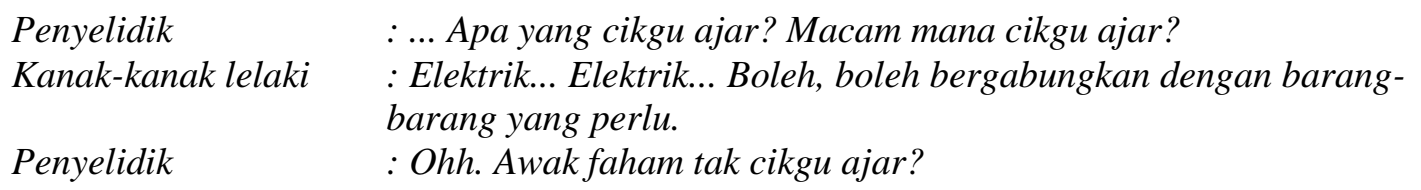


Malaysian Journal of Social Sciences and Humanities (MJSSH), Volume 6, Issue 11, (page 110 - 126), 2021

DOI: https://doi.org/10.47405/mjssh.v6i11.1135

$\begin{array}{ll}\text { Kanak-kanak lelaki } & \text { :Faham. Tapi diri saya ajar lagi faham. Diri saya kata kalau } \\ & \text { bateri tu bersambung dengan tempat untuk cas bateri, lepas tu } \\ & \text { haa... Tempat untuk cas bateri tu akan pergi ke handphone. } \\ & \text { :Ohh... Jadi kalau awak belajar sendiri awak lagi faham daripada } \\ \text { Penyelidik } & \text { cikguajar. } \\ \text { Kanak-kanak lelaki } & \text { :Haah. Dengan kawan-kawan. }\end{array}$

Kanak-kanak dalam kajian ini juga mengatakan bahawa guru menggunakan kaedah yang lebih berpusatkan guru dalam menjelaskan konsep elektrik. Guru masih menggunakan teknik chalk and talk dalam proses pengajaran yang dijalankan di dalam kelas. Hal ini akan sangat mempengaruhi kefahaman kanak-kanak dalam konsep Sains yang melibatkan elektrik:

Penyelidik Cikgu dekat kelas ajar macam mana? Macam mana awak boleh
faham bila cikgu ajar dekat kelas? Dia guna aktiviti apa? Dia
bermain ke? Dia tunjuk dalam kelas ke? Tunjuk dalam gambar ke?
Kanak-kanak perempuan : Dia tunjuk dalam whiteboard. Jadi, jadi, jadi saya tahulah pasal
elektrik tu.

\section{Faktor ibu bapa}

Di samping itu, ibu bapa juga mempengaruhi pemahaman kanak-kanak terhadap elektrik. Dalam kajian ini, peranan bapa sangat memainkan peranan yang besar dalam memberi kefahaman kepada kanakkanak lelaki itu tentang elektrik. Bapa kanak-kanak lelaki berkenaan telah mendedahkan tentang konsep elektrik kepadanya dengan menjelaskan konsep tersebut. Hal ini kerana kanak-kanak lelaki berkenaan dapat menjelaskan konsep elektrik berdasarkan penjelasan yang telah diberikan oleh bapanya:

\section{Penyelidik $\quad$ :..Jadi dalam ahli keluarga awak, siapa pernah cakap tentang bateri? \\ Kanak-kanak lelaki $\quad$ :Haa..Ayah saya.}

Pendedahan yang diberikan oleh ibu bapa di rumah memberi gambaran kepada tentang konsep asas elektrik terutamanya berkenaan sel kering. Mereka boleh menjelaskan berkenaan fungsi sel kering dengan kefahaman yang telah mereka peroleh. Sebagai contoh, kanak-kanak lelaki berkenaan boleh menjelaskan fungsi sel kering yang ada:

\section{Penyelidik $\quad$ :..Apa dia fungsi bateri ni? \\ Kanak-kanak lelaki $\quad$ :Fungsi bateri ni, haa..ada..Ada yang boleh cas, ada yang tak boleh cas.}

Menerusi perbualan di atas, kanak-kanak lelaki dapat mengetahui secara asas fungsi sel kering berdasarkan pendedahan awal yang telah diberikan oleh bapanya ketika di rumah. Namun begitu, berbeza pula jawapan yang diberikan oleh kanak-kanak perempuan apabila dia tidak boleh memberikan fungsi sel kering apabila ditemu bual. Perkara berkemungkinan terjadi kerana kanak-kanak perempuan tersebut ada menyatakan bahawa ibu bapanya tidak pernah menjelaskan tentang konsep elektrik di rumah semasa proses temu bual dijalankan.

\section{Penyelidik $\quad$ :..Dekat rumah ada tak family yang cakap tentang elektrik atau bateri?}

Kanak-kanak perempuan : Tak ada.

Kefahaman kanak-kanak boleh diketahui dengan lebih terperinci apabila proses temu bual dijalankan selepas ujian diagnostik dijalankan kepada mereka. Menerusi proses tersebut, penyelidik dapat mencungkil kefahaman sebenar kanak-kanak terhadap konsep elektrik berbanding ujian diagnostik semata-mata. Hal ini kerana apabila ditemu bual, kanak-kanak perempuan berkenaan menyatakan 
bahawa kebanyakan jawapan yang diberikan hanya berdasarkan tekaan sahaja. Kanak-kanak perempuan berkenaan belum menguasai konsep elektrik sepenuhnya.

\section{Faktor luar}

Selain faktor murid, guru dan ibu bapa, faktor luar juga memainkan peranan dalam kefahaman kanakkanak terhadap pembelajaran konsep elektrik. Faktor luar yang boleh terlibat adalah seperti televisyen, buku, internet dan juga rakan. Hasil temu bual yang dijalankan, faktor luar yang melibatkan televisyen memainkan peranan yang besar dalam menjelaskan kefahaman terhadap elektrik. Perkara ini dapat dilihat apabila kanak-kanak lelaki yang menyatakan bahawa dia lebih memahami konsep ini apabila menonton televisyen:

\section{Penyelidik \\ Kanak-kanak lelaki \\ Penyelidik}

Kanak-kanak lelaki
: Kaedah mana yang senang nak faham tentang elektrik.

: Daripada tv.

: Dari tv. Tv lagi senang nak faham ya. Ok, awak rasa sebab apa tv lagi senang nak faham?

: Sebab tv tu, dia akan bagi tahu apa yang akan saya fikirkan pasal elektrik. Jadi,kalau buku, dia tak bagi tahu apa yang saya fikirkan.

Selepas ditemu bual, penyelidik mendapati bahawa kanak-kanak berkenaan lebih terdorong untuk memahami sesuatu konsep menerusi televisyen berbanding buku. Kanak-kanak tersebut ada merujuk buku berkenaan elektrik, tetapi lebih mudah untuk memahami konsep tersebut menerusi televisyen. Hal ini kerana kanak-kanak merasakan dengan menonton televisyen, mereka mudah mendapat maklumat secara terus dan memberi gambaran yang lebih jelas dalam memahami sesuatu konsep.

Tambahan itu, buku juga merupakan faktor yang dapat memberi kefahaman kepada kanak-kanak terhadap elektrik. Hal ini kerana kanak-kanak tersebut juga merujuk buku dalam mengetahui lebih lanjut terhadap konsep tersebut. Malahan, hasil analisis dokumen buku yang digunakan dalam pembelajaran mereka di kelas menunjukkan buku dapat memberi gambaran yang baik dalam konsep ini. Penggunaan Augmented Reality $(A R)$ dalam buku pembelajaran mereka di kelas membantu mereka memahami konsep ini dengan lebih baik kerana penggunaan bahan visual yang lebih menarik .

Di samping itu, kanak-kanak juga turut mendapatkan maklumat daripada internet. Selain televisyen, mereka juga mendapatkan maklumat menerusi Youtube untuk memahami konsep elektrik ini. Cara penyampaian menerusi televisyen dan Youtube merupakan antara perkara yang menjadi pendorong kanak-kanak untuk memahami sesuatu konsep terutama konsep Sains kerana pemaparan visual yang lebih menarik untuk difahami.

\section{Penyelidik \\ : Awak pernah belajar tak dengan Youtube? \\ Kanak-kanak lelaki \\ : Saya tengok dalam Youtube, lepas tu ayah saya tolong tuliskan. \\ Haa.. Macam mana nak sambungkan elektrik.}

Perbualan antara rakan juga tidak terlepas daripada menjadi faktor pemahaman kanak-kanak memahami konsep ini. Kedua-dua peserta kajian menyatakan bahawa mereka turut mengetahui berkaitan elektrik apabila berkomunikasi antara rakan mereka. Hal ini menunjukkan bahawa faktor luar juga turut terlibat dalam mempengaruhi kefahaman mereka terhadap konsep elektrik.

Pelbagai faktor yang telah mempengaruhi kefahaman kanak-kanak terhadap konsep elektrik. Antara faktor yang terlibat adalah faktor murid, guru, ibu bapa dan faktor luar seperti televisyen, buku, internet dan juga rakan. Justeru, faktor luar melibatkan televisyen dilihat memberi impak yang besar terhadap kefahaman kanak-kanak terhadap elektrik dan juga menjadi antara faktor yang menyebabkan boleh berlakunya miskonsepsi. 


\section{Perbincangan Kajian}

Berdasarkan hasil temu bual yang dijalankan, kanak-kanak lelaki mempunyai pengetahuan yang lebih mendalam berkaitan konsep elektrik. Sesi temu bual yang dijalankan memberi penjelasan yang lebih mendalam mengapa hal ini boleh terjadi. Situasi ini berlaku disebabkan kanak-kanak lelaki lebih terdedah terhadap elektrik berbanding kanak-kanak perempuan. Mereka dapat menyampaikan kembali maklumat yang diketahui kepada penyelidik mengikut kemampuan mereka dengan lebih baik berbanding kanak-kanak perempuan. Terdapat kajian yang menyatakan bahawa murid lelaki mampu memperoleh keputusan yang lebih baik dalam Sains berbanding kanak-kanak perempuan (Glory \& Sopuruchi 2017; Quinn et al., 2015; Griffith 2010). Kajian yang dijalankan ini bersepadan dengan kajian terdahulu yang menunjukkan kanak-kanak lelaki mempunyai kefahaman berkaitan Sains yang lebih baik berbanding perempuan. Hal ini berkemungkinan terjadi kerana murid lelaki lebih mudah memahami perkara yang abstrak seperti elektrik.

Berdasarkan kajian ini juga, terdapat beberapa faktor yang mempengaruhi kefahaman kanak-kanak tadika dalam elektrik. Antara faktor tersebut adalah faktor murid, ibu bapa, guru serta faktor luar seperti televisyen, buku, rakan serta internet. Murid sendiri menjadi salah satu faktor yang menjadi penyumbang boleh berlakunya miskonsepsi. Jika dilihat kepada faktor murid, kanak-kanak lelaki dalam kajian ini menunjukkan minat yang lebih mendalam kepada pembelajaran yang melibatkan elektrik manakala kanak-kanak perempuan sebaliknya. Perkara ini bersepadan dengan kajian yang dilakukan oleh Halim et al. (2019) dan Leong (2012) yang menyatakan faktor miskonsepsi berlaku dalam kalangan murid adalah disebabkan kurang minat terhadap tajuk elektrik dalam kalangan murid sekolah menengah. Hal ini kerana mereka beranggapan pembelajaran yang melibatkan elektrik bersifat abstrak. Pembelajaran yang abstrak sukar dipelajari oleh murid kerana tajuk tersebut sukar dilihat dengan mata kasar atau tidak dapat dirasa dengan lima pancaindera yang ada (Duda et al., 2020). Justeru, kajian ini menunjukkan kanak-kanak lelaki lebih berminat memahami tentang elektrik berkemungkinan kerana pendedahan yang telah diperoleh dan lebih cenderung kepada pembelajaran yang berbentuk abstrak berbanding kanak-kanak perempuan.

Selain itu, jawapan yang diberikan oleh kanak-kanak semasa temu bual berkaitan pemikirannya terhadap elektrik menunjukkan berlakunya miskonsepsi. Kanak-kanak mempunyai kefahaman sedia ada tetapi jawapan yang diberikan tidak menepati konsep saintifik. Perkara ini menunjukkan mereka mengalami miskonsepsi terhadap pembelajaran Sains (Mareshal, 2016). Hal ini boleh dikaitkan dengan teori konstruktivisme yang menunjukkan kanak-kanak memahami sesuatu berdasarkan pengalaman sedia ada mereka dan dikembangakan secara aktif (Piaget, 1977). Mereka akan menjawab persoalan yang diberikan berdasarkan pengalaman yang pernah dilalui tanpa dapat mengaitkan dengan konsep Sains yang saintifik. Justeru, murid perlu dibimbing dengan konsep saintifik yang betul supaya mengelakkan berlakunya miskonsepsi terutama sejak di awal usia lagi supaya tidak dibawa hingga ke peringkat yang seterusnya.

Faktor lain yang turut mempengaruhi pembelajaran terhadap elektrik kepada kanak-kanak tadika adalah faktor guru. Guru merupakan insan yang turut penting dalam mempengaruhi kefahaman kepada murid berkaitan elektrik kerana mereka yang mengajar tentang tajuk tersebut. Cara penyampaian yang kurang menarik kepada kanak-kanak tadika memberi kesan boleh berlakunya miskonsepsi. Hal ini terjadi apabila kanak-kanak tersebut tidak dapat menyatakan secara jelas kefahaman yang diperoleh berdasarkan pengajaran guru. Situasi ini boleh terjadi disebabkan penggunaan pengajaran yang kurang menarik daripada guru. Kajian daripada Hermita et al. (2017) dan Halim et al. (2019) turut menyatakan bahawa teknik pengajaran guru memberi kesan berlakunya miskonsepsi dalam kalangan murid. Guru yang masih menggunakan teknik pengajaran tradisional yang hanya melibatkan papan tulis dalam menerangkan konsep elektrik membawa berlakunya miskonsepsi. Kanak-kanak tadika yang berada pada peringkat praoperasi berdasarkan teori Piaget, memerlukan objek yang maujud dalam memahami konsep yang abstrak seperti elektrik. Mereka dapat memahami konsep yang saintifik dengan baik apabila ditunjukkan secara jelas dengan menggunakan objek maujud.

Tambahan itu, faktor ibu bapa juga menjadi salah satu faktor yang mempengaruhi kefahaman kanakkanak berkaitan elektrik. Berdasarkan jawapan yang diberikan oleh kanak-kanak lelaki dalam kajian 
ini, bapa merupakan insan yang dapat mempengaruhi kefahamannya dalam memahami elektrik. Jawapan yang diberikan menunjukkan kefahaman yang diperoleh adalah berdasarkan informasi yang pernah diberikan oleh bapa kanak-kanak lelaki tersebut. Pendedahan yang diberikan oleh ibu bapa menerusi komunikasi dengan anaknya akan mempengaruhi kefahaman anak mereka terutama dalam pembelajaran Sains (Gutwill \& Allen, 2010; Vandermaas-Peeler et al., 2016). Hal ini menunjukkan ibu bapa merupakan golongan yang dapat mempengaruhi kefahaman kanak-kanak. Kajian yang dibuat oleh Oke Oloruntegbe (2012) menyatakan bahawa ibu bapa yang mempunyai latar belakang pekerjaan berkaitan dengan Sains akan dapat menjelaskan tentang Sains lebih baik berbanding bukan yang berlatar belakang Sains. Kajian menunjukkan pekerjaan ayah kanak-kanak lelaki berkenaan berkait dengan Sains. Justeru, bapa kanak-kanak lelaki tersebut dapat menjelaskan konsep elektrik kepada kanak-kanak berkenaan pada awal usia. Kajian Gaspard (2016) menunjukkan bahawa ibu bapa yang mempunyai pemikiran yang positif terhadap Sains akan memberikan kesan yang baik terhadap pembelajaran Sains kanak-kanak. Justeru, kajian ini turut sama mendapati bahawa penjelasan yang dilakukan oleh bapa di rumah dalam mempengaruhi kefahaman kanak-kanak berkemungkinan kerana bapa mempunyai pemikiran yang positif terhadap Sains.

Di samping itu, faktor luar juga memberikan kesan berlakunya miskonsepsi terutama daripada aspek televisyen, rakan, internet serta buku. Kanak-kanak mudah mempelajari sesuatu menerusi televisyen terutama kanak-kanak visual. Namun begitu, televisyen turut memberi kesan boleh berlakunya miskonsepsi (Duda et al., 2020). Pemahaman menerusi televisyen perlu dibimbing oleh orang yang berpengetahuan supaya kanak-kanak tidak terdedah kepada miskonsepsi. Selain televisyen, penggunaan internet seperti menonton video di Youtube turut menyumbang kepada pemahaman kanakkanak terhadap elektrik menerusi visual. Kedua-dua medium ini memberi peluang kepada kanak-kanak mempelajari elektrik secara lebih santai dengan penggunaan visual yang dipaparkan. Hal ini akan memudahkan mereka memahami tentang elektrik. Rakan sebaya turut menjadi penyumbang kefahaman kanak-kanak memahami elektrik kerana mereka kerap berkomunikasi antara satu sama lain. Walaupun begitu, miskonsepsi boleh terjadi jika perkara yang disampaikan tidak bertepatan dengan konsep saintifik (Halim et al., 2019). Penyampaian maklumat yang tidak tepat boleh menyebabkan faktor miskonsepsi berlaku dalam kalangan kawan- kawan. Buku juga merupakan perkara yang dapat menyumbang kepada kefahaman kanak-kanak berkaitan elektrik dalam kajian ini. Kanak-kanak turut merujuk buku dalam mengetahui tentang elektrik. Namun begitu, terdapat kajian yang menyatakan bahawa buku boleh menyumbang kepada miskonsepsi apabila terdapat kesalahan istilah yang digunakan yang boleh menjejaskan kefahaman individu (Kurniawan \& Maryanti, 2018; Sanders \& Makotsa, 2016). Oleh itu, bimbingan perlu diberikan supaya mengelakkan berlakunya miskonsepsi menerusi buku.

\section{Kesimpulan}

Kesimpulannya, miskonsepsi berkaitan pembelajaran Sains melibatkan elektrik boleh berlaku sejak di tadika lagi. Kanak-kanak lelaki atau kanak-kanak perempuan dalam kajian ini tidak terlepas daripada berlakunya miskonsepsi terhadap elektrik. Mereka mempunyai pengetahuan tentang konsep asas elektrik tetapi perlu dibimbing dengan betul supaya boleh memahami konsep secara betul. Di samping itu, faktor-faktor yang terlibat dalam mempengaruhi kefahaman kanak-kanak tadika berkaitan elektrik adalah faktor murid, guru, ibu bapa serta faktor luar seperti televisyen, buku teks, internet dan juga rakan. Kanak-kanak lelaki dalam kajian ini menunjukkan kefahaman yang lebih baik tentang elektrik berbanding kanak-kanak perempuan. Kanak-kanak lelaki turut memaklumkan bahawa faktor luar yang melibatkan televisyen merupakan faktor yang sangat mempengaruhi dirinya dalam memahami tentang elektrik. Oleh itu, dapat diketahui bahawa faktor luar merupakan faktor yang memainkan peranan penting dalam memberi kefahaman kepada kanak-kanak tentang elektrik.

Kajian yang dilaksanakan ini dapat membantu guru dan juga ibu bapa dalam memberi pendedahan awal konsep asas Sains berkaitan elektrik. Guru boleh menggunakan hasil kajian ini dalam menangani miskonsepsi berkaitan pembelajaran melibatkan elektrik ke atas kanak-kanak tadika. Hal ini kerana apabila masalah miskonsepsi dapat diatasi sejak awal lagi, kanak-kanak atau murid tidak akan membawa salah faham konsep ke peringkat seterusnya. Sebagai contoh, kefahaman mereka berkaitan 
fungsi sel kering dalam sesuatu litar. Apabila salah faham berkaitan konsep Sains dapat diatasi, mereka akan dapat memahami sesuatu konsep saintifik dengan lebih baik.

Limitasi dalam kajian ini adalah temu bual dapat dijalankan ke atas dua orang kanak-kanak tadika sahaja dapat dilaksanakan disebabkan kes pandemik Covid-19 yang berlaku dan hanya melibatkan tadika swasta. Kajian lanjutan yang boleh dilaksanakan untuk kajian seterusnya adalah pengkaji boleh melibatkan peserta kajian yang lebih ramai serta melibatkan pelbagai tadika yang ada. Malahan, pengkaji lain juga boleh menumpukan faktor tertentu sahaja dalam melihat miskonsepsi yang berlaku. Justeru, faktor yang boleh menyebabkan miskonsepsi boleh diatasi apabila diketahui dengan baik.

\section{Rujukan}

Alveirinho, D., Bento, J. \& Nunes, M. (2017). the Science Experiment and the Playful Learning: Window of Opportunity for Curricular Articulation in the Transition Between Preschool Education and Primary Education. ICERI2017 Proceedings, 1, 8629-8635.

Ameyaw Y., Sarpong L. (2011). Integrating ICT in The Pedagogical Skills of Teachers in Some Basic Schools in the Ga South District in The Greater-Accra Region of Ghana. Journal of Education, 1 (1), 1-9.

Arslan, H., Cigdemoglu, C. \& Moseley, C. (2012). A Three-Tier Diagnostic Test to Assess PreService Teachers' Misconceptions about Global Warming, Greenhouse Effect, Ozone Layer Depletion, and Acid Rain. International Journal of Science Education - INT J SCI EDUC, 34, 120.

Aydeniz, M., Bilican, K., \& Kirbulut, Z. D. (2017). Exploring Pre-Service Elementary Science Teachers' Conceptual Understanding of Particulate Nature of Matter through Three-Tier Diagnostic Test. International Journal of Education in Mathematics, Science and Technology, 5(3), 221-234. https: //doi.org/10.18404/ijemst.296036.

Azaman Ishar, Ramlee Mustapha \& Shafie Shamuddin. (2009). Kajian Tinjauan terhadap permasalahan pengajaran dan pembelajaran lukisan kejuruteraan menurut persepsi guru dan pelajar. 15th International Conference on Education. Brunei. Institut Pendidikan Sultan Hassanal.

Bayuni, T.C., Sopandi, W. \& Sujana, A. (2018). Identification misconception of primary school teacher education students in changes of matters using a five-tier diagnostic test. Journal of Physics: Conference Series, 1013, 12086.

Berg, E., D. (1991). Physics's Misconceptions and Remediation. Salatiga: Universitas Satyawacana.

Bestiantono, D.S., Sa'diyah, E.H., Rachmatya, R., Mubarok, H., Adam, A.S. \& Suprapto, N. (2019). University Students' Misconception in Electromagnetism. Journal of Physics: Conference Series, 1417(1). https: //doi.org/10.1088/1742-6596/1417/1/012074.

Brooks, S. \& Gelman, A. (1998). General Methods for Monitoring Convergence of Iterative Simulations. J. Comput. Graphi. Stat, 7, 434-455.

Bucat, R. B. (2015). Using the cognitive conflict strategy with classroom Chemistry demonstrations. Chemistry Education: Best Practices, Opportunities and Trends Weinheim, Germany: WileyVCH Verlag GmbH \& Co. KGaA, 447-468

Bustamante, A.S., White, L.J. \& Greenfield, D.B. (2017). Approaches to learning and school readiness in Head Start: Applications to preschool science. Learning and Individual Differences, 56, 112 118.

Bustamante, A.S., White, L.J. \& Greenfield, D.B. (2018). Approaches to learning and science education in Head Start: Examining bidirectionality. Early Childhood Research Quarterly, 44, $34-42$.

Can, B., Yıldız Demirtaş, V. \& Altun, E. (2017). The effect of project-based Science education programme on scientific process skills and conceptions of kindergarten students. Journal of Baltic Science Education. 16, 395-413. https://doi.org/10.33225/jbse/17.16.395.

Chen, C., Sonnert, G., Sadler, P.M., Sasselov, D. \& Fredericks, C. (2020). The impact of student misconceptions on student persistence in a MOOC. Journal of Research in Science Teaching. 57(6): 879-910. 
Clement, J. (1993). Using bridging analogies and anchoring intuitions to deal with students' preconceptions in physics. Journal of Research Scienece Taeaching, 30(10), 1241-1247.

Desstya, A., Prasetyo, Z.K., Suyanta, Susila, I. \& Irwanto. (2019). Developing an instrument to detect science misconception of an elementary school teacher. International Journal of Instruction, 12(3), 201-218.

Diani, R., Latifah, S., Anggraeni, Y.M. \& Fujiani, D. (2018). Physics Learning Based on Virtual Laboratory to Remediate Misconception in Fluid Material. Tadris: Jurnal Keguruan dan Ilmu Tarbiyah, 3(2), 167.

Duda, H.J., Wahyuni, F.R.E. \& Setyawan, A.E. (2020). Plant biotechnology: Studying the misconception of biology education students. AIP Conference Proceedings, 2296:1-10.

Galvin, E., \& Simmie, M. G. (2015). Identification of misconceptions in the teaching of biology: A pedagogical cycle of recognition, reduction and removal. Higher Education of Social Science, $8(2), 1-8$.

Gaspard, J. D. (2016). The influence of selected factors on the Science achievement of eighth grade students in Louisiana. Louisiana State University, Doctoral Dissertations. 496.

Glory, G.-E., \& Sopuruchi, I. (2017). Influence of Gender on Interest and Academic Achievement of Students in Integrated Science in Obio Akpor Local Government Area of Rivers State. European Scientific Journal, ESJ, 13(10): 272.

Griffith, A. L. (2010). Persistence of women and minorities in STEM field majors: Is it the school that matters. Economics of Education Review, 29: 911-922.

Gürefe, N., Yarar, S. H., Pazarbasi, B. N., \& Es, H. (2014). The effect of conceptual change texts on understanding of height concept of secondary school 5th class students. International Journal of Educational Studies in Mathematics, 1(1), 58-68.

Gurel, D. K., Eryilmaz, A., \& McDermott, L. C. (2017). Development and application of a four-tier test to assess pre-service Physics teachers' misconceptions about Geometrical Optics. Research in $\begin{array}{llll}\text { Science } \quad \& \quad \text { Technological } \quad \text { Education, } & 35(2), & 238-260 .\end{array}$ https://doi.org/10.1080/02635143.2017.1310094.

Gutwill, J. P., and Allen, S. (2010). Facilitating family group inquiry at science museum exhibits. Sci. Educ, 94: 710-742.

Halim, A., Lestari, D. \& Mustafa. (2019). Identification of the causes of misconception on the concept of dynamic electricity. Journal of Physics: Conference Series, 1280(5). https://doi.org/10.1088/1742-6596/1280/5/052060.

Halim, A., Yusrizal, Mazlina, H., Melvina \& Zainaton. (2018). Questioning skill of science teacher from the students perscpective in senior high school. Journal of Physics: Conference Series, 1088: 12109.

Hermita, N., Suhandi, A., Syaodih, E., Samsudin, A., Isjoni, Johan, H., Rosa, F., Setyaningsih, R., Sapriadil \& Safitri, D. (2017). Constructing and Implementing a Four Tier Test about Static Electricity to Diagnose Pre-service Elementary School Teacher' Misconceptions. Journal of Physics: Conference Series, 895(1).

Hisyamuddin Abdul Razab \& Amir Hamzah Sharaai. (2012). Kaedah nyanyian dalam mengatasi masalah miskonsepsi dalam kalangan pelajar tahun tiga dalam topik magnet. Persidangan Kebangsaan Pembangunan dan Pendidikan Lestari 2012.

Kang, H., Lawrence, C. S., Sukjin K.\& Taehee, N. (2010). Cognitive conflict and situational interest as factors influencing conceptual change. International Journal of Environmental \& Science Education, 5(4), 383-405.

Kiray, S.A., Aktan, F., Kaynar, H., Kilinc, S. \& Gorkemli, T. (2015). A descriptive study of preservice science teachers' misconceptions about sinking-floating. Asia-Pacific Forum on Science Learning and Teaching, 16(2).

Kollöffel, B. \& Jong, T. (2013). Conceptual Understanding of Electrical Circuits in Secondary Vocational Engineering Education: Combining Traditional Instruction with Inquiry Learning in a Virtual Lab. Journal of Engineering Education.102.

Kumandaş, B. (2015). Misconceptions in biology education: A Review of Relevant Research. Unpublished Master's Thesis. Bilkent University, Ankara. http://hdl.handle.net/11693/28941.

Kurniawan, D.T. \& Maryanti, S. (2018). Analysis of Math Teacher Candidates' Misconception on the $\begin{array}{lllll}\text { Dynamic Electricity Concept. Scientiae Educatia, } & 7(1), \quad 67 .\end{array}$ http://doi.org/10.24235/sc.educatia.v7i1.2481. 
Kurniawan, R., \& Arief, A. (2015). Identifikasi Miskonsepsi Hukum Newton Tentang Gerak Bagi Siswa Sekolah Menengah Atas Di Kabupaten Nganjuk. 4(2), 1-3.

Leong F. N. (2012). Penggunaan Strip Komik Bagi Meningkatkan Pencapaian Murid Dalam Topik Kitaran Air Tahun 5. Kajian Tindakan IPG Tunku Bainun Pulau Pinang.

Mareschal, D. (2016). The neuroscience of conceptual learning in science and mathematics. Current Opinion in Behavioral Sciences, 10, 114-118. http://doi.org/10.1016/j.cobeha.2016.06.001.

Marhadi, H., Lazim, L., Hermita, N., Alpusari, M., Widyanthi, A., Suhandi, A., Sutarno, S., Mahbubah, K. \& Samsudin, A. (2019). Implementing a four-tier diagnostic test to assess elementary school students' on electricity magnetism concept. Journal of Physics: Conference Series, 1157(3), 978-979. http://dx.doi.org/10.1088/1742-6596/1157/3/032020.

Mazlini Adnan, Aminah Ayob, Tek, O, E., Mohd Nasir Ibrahim, Noriah Ishak \& Jameyah Sheriff. (2017). Memperkasa pembangunan modal insan Malaysia di peringkat kanak-kanak: Kajian kebolehlaksanaan dan kebolehintegrasian pendidikan STEM dalam kurikulum PERMATA Negara. Geografia Online Malaysian Journal of Society and Space, 12(1), 29-36. http://doi.org/10.7456/1080SSE/185.

McClure, E. R., Guernsey, L., Clements, D. H., Bales, S. N., Nichols, J., Kendall-Taylor, N., \& Levine, M. H. (2017). STEM starts early: Grounding science, technology, engineering, and math education in early childhood. New York: The Joan Ganz Cooney Center at Sesame Workshop.

Merriam, S. B. (2009). Qualitative Research: A Guide to Design and Implementation (2nd ed.). USA: Jossey Bass.

Miles, M. B., \& Huberman, A. M. (1994). Qualitative data analysis: An expand sourcebook. (2nd ed). Thousand Oaks: California.

Moodley, K., \& Gaigher, E. (2017). Teaching Electric Circuits: Teachers' Perceptions and Learners' Misconceptions. Research in Science Education. https://doi.org/10.1007/s11165-017-9615-5.

Nixon, R. S., Campbell, B. K., \& Luft, J. A. (2016). Effects of subject-area degree and classroom experience on new chemistry teachers' subject matter knowledge. International Journal of Science Education, 38(10), 1636-1654.

Ojose, B. (2008). Applying Piaget's Theory of Cognitive Development to Mathematics Instruction. The Mathematics Educator 18.

Oke Oloruntegbe, K. (2012). Would Science Background Be a Factor in Parents Helping Students Establish a Match between School Science and Home Activities? Education, 2(1), 1-7.

Patton, M. Q. (2002). Qualitative Evaluation and Research Method (3rd ed.). California: Sage Publications, Inc.

Piaget, J. (1952). The origins of intelligence in children. London: Routledge and Kegan Paul.

Piaget, J. (1977). The development of thought: Equilibration of cognitive structures. New York: The Viking Press.

Quinn, David M., \& Coor, N. (2015). Science Achievement Gaps by Gender and Race/Ethnicity in Elementary and Middle School: Trends and Predictors. Educational Research., 44(6): 336-346.

Ravanis, K. (2017). Ravanis, K. (2017). Early Childhood Science Education: state of the art and perspectives. Journal of Baltic Science Education, 16(3), 284-288.

Sadler, P. M., Sonnert, G., Coyle, H. P., Cook-Smith, N., \& Miller, J. L. (2013). The influence of teachers' knowledge on student learning in middle school physical science classrooms. American Educational Research Journal, 50(5), 1020-1049.

Sanders, M. \& Makotsa, D. (2016). The possible influence of curriculum statements and textbooks on misconceptions: The case of evolution. Education as Change, 20(1): 216-238.

Sanger, M. J. \& Greenbowe, T. J. (1997). Common student misconceptions in electrochemistry: Galvanic, electrolytic, and concentration cells. Journal of Research Science Teaching, 34(4), 377398. https://doi.org/10.1002/(SICI)1098-2736(199704)34.

Sen, S., \& Yilmaz, A. (2017). The Development of a Three-tier Chemical Bonding Concept Test. Journal of Turkish Science Education (TUSED), 14(1), 110-126. http://doi.org/10.12973/tused.10193a.

Sholihat, F. N., Samsudin, A., \& Nugraha, M. G. (2017). Identifikasi Miskonsepsi dan Penyebab Miskonsepsi Siswa Menggunakan Four-Tier Diagnostic Test Pada SubMateri Fluida Dinamik: Azas Kontinuitas. Jurnal Penelitian \& Pengembangan Pendidikan Fisika, 3(2), 175-180. 
Soeharto, Csapó, B., Sarimanah, E., Dewi, F.I. \& Sabri, T. (2019). A review of students' common misconceptions in science and their diagnostic assessment tools. Jurnal Pendidikan IPA Indonesia, 8(2), 247-266. http://doi.org/10.15294/jpii.v8i2.18649.

Suliyanah, Putri, H. N. P. A., \& Rohmawati, L. (2018). Identification student's misconception of heat and temperature using three-tier diagnostic test. Journal of Physics: Conference Series, 997(1). http://doi.org/10.1088/1742-6596/997/1/012035.

Suma, K., Sadia, I.W. \& Pujani, N.M. (2019). Effect of Physics module based on activity and conceptual change text on students' conception of static electricity. Journal of Physics: Conference Series, 1321, 32072. https://doi.org/10.1088/1742-6596/1321/3/032072.

Taber, K. S. (2014). Constructing and communicating knowledge about Chemistry and Chemistry education. Chemistry Education Research and Practice, 15(1): 5-9.

Taslidere, E. (2016). Development and Use of a Three- Tier Diagnostic Test to Assess High School Students' Misconceptions about the Photoelectric Effect. Research in Science \& Technological Education, 34(2), 164-186. https://doi.org/10.1080/02635143.2015.1124409.

Taufik.M. (2012). Remediasi miskonsepsi mahasiswa calon guru fisika pada konsep Gaya melalui penerapan model siklus belajar (learning cycle) 5E. Jurnal UNS Semarang.

Trundle, K. C. \& Smith, M. M. (2017). Preschool Science Learning (March): 80-87.

Vandermaas-Peeler, M., Westerberg, L., Fleishman, H., Sands, K., and Mischka,M. (2018). Parental guidance of young children's mathematics and scientific inquiry in games, cooking, and nature activities. Int. J. Early Years Educ. 5, 27-46.

Yagbasan, R., \& Gulcicek, C. (2003). Describing the characteristics of misconceptions in science teaching. Pamukkale University Journal of Education, 1(3): 102-120. 